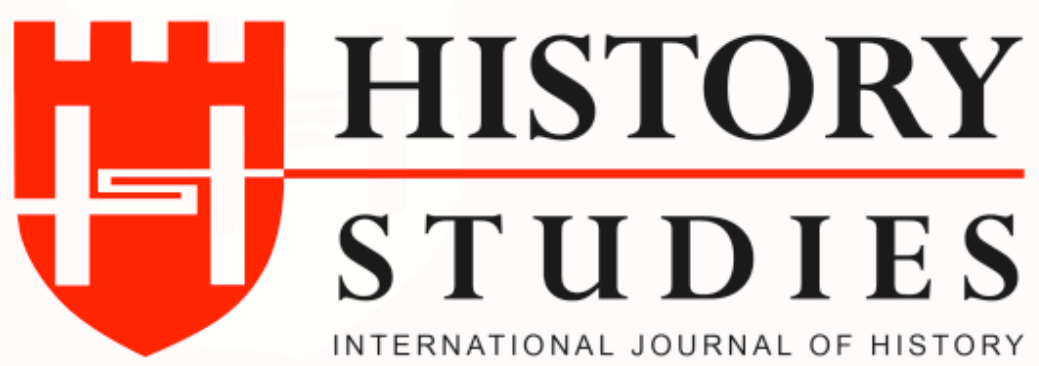

ISSN: 13094173 (Online) 1309 - 4688 (Print)

Volume 9 Issue 5, p. 143-154, December 2017

DOI: $10.9737 /$ hist.2017.564

\title{
İki Savaş Arası Dönem Türk Dış ve Güvenlik Politikasında Oniki Ada, 1923-1939
}

The Dodecanese Islands in Turkish Foreign and Security Policies in the Interwar Period, 1923-1939

\author{
Dr. Hazal PAPUÇÇULAR
}

(ORCID: 0000-0002-2035-133X)

Ístanbul Kültür Üniversitesi - İstanbul

\begin{abstract}
Öz:Bu makale, iki savaş arası dönemde Oniki Ada'nın Türk dış politikası ve güvenlik anlayışındaki yerini incelemektedir. Dönemin dış politikasını anlatan birçok eserin atıfta bulunduğu "Oniki Ada'dan gelen Italyan tehdidi" söyleminin tam olarak neye tekabül ettiğini İtalyan, Türk ve Ingiliz arşiv belgelerine dayanarak irdelemektedir. Bu bağlamda bu çalışma, Türkiye ana karası ile karşılaştırıldığında coğrafi olarak çok küçük olmalarına rağmen bu adaların Ankara için büyük siyasi ve askerî sorunlara işaret ettiğine dikkat çekmektedir. Oniki Ada'nın İtalyanlar tarafindan askerî bir üs olarak formüle edildiği bu yıllarda, adalarda gerçekleşen her askerî hareketliliğin Türkiye'deki siyasi ve askerî yansımalarına örnekleriyle değinilmektedir. Bu örnekler, bir taraftan, adaların Türk dış politikasının önemli ve dönem dönem belirleyici bir parçasını oluşturduğunu gösterirken, diğer taraftan Batı ve Güneybatı Anadolu'daki askerî düzenlemelerin neredeyse tamamının bu adalara endeksli şekilde yapıldı̆̆ını söylemektedir. Adaların Türk dış politikası için önemine ek olarak bu çalışma, mevcut literatürün çoğunlukla 1950 sonrast için ele aldığ Ege'deki sinır sorunlarının bu dönemden başlayarak ortaya çıktığını arşiv belgelerindeki örnekler üzerinden göstermektedir. Meis (Kastellorizo) Adası'ndaki sınır çizme arayışına ek olarak, Ege'nin genelinde sınır oluşturma çabasına, ihlal ve işgallere ü̧̈ devlet- Türkiye, Italya, Yunanistan- ekseninde değinmektedir.
\end{abstract}

Anahtar Kelimeler: Oniki Ada, Türk Dış Politikası, İki Savaş Arası Dönem, Ege Adaları

Abstract: This article analyses the place of the Dodecanese Islands in Turkish foreign and security policies in the interwar period. Based on the archival resources of Turkey, Italy and Britain, it tries to put forward the meaning of the "Italian threat coming from the Dodecanese Islands" referred by various sources dealing with the foreign policy of the time. It emphasizes how these tiny islands could pose political and military threat to the Anatolian mainland. Various examples are given to designate the reflection of the aggressive Italian stance in the Aegean Sea on Turkish politics. In this respect, this study argues that the Dodecanese factor became one of the most important determinants of Turkish foreign policy in general as well as of the Turkish military proceedings in Western and Southwestern Anatolia in this time frame. In addition to the importance of the islands for interwar Turkish foreign policy and strategy, this article also shows that the recent boundary problems in the Aegean Sea date back to the 1920s. These problems are emphasized with respect to the efforts of the parties to solve the matter, to mutual violations, and even to acts of occupation of some of the islets, based on the relationship between Turkey, Italy and Greece.

Keywords: The Dodecanese Islands, Turkish foreign policy, Interwar Period, Aegean Islands 
Giriş: 16. yüzyıldan itibaren kesintisiz şekilde Osmanlı İmparatorluğu'nun hâkimiyeti altında bulunan Oniki Ada'nın İmparatorluğun egemenliğinden çıkma süreci 19. yüzyılda başladı. 19. yüzyılda, Yunanistan'ın bağımsızlı̆̆ 1 ile sonuçlanacak olan Yunan İsyanı sırasında Ege Denizi'nde, içinde Oniki Ada grubunun da bulunduğu bazı adalar isyana katılmış, fakat isyan sonrasında bu adaların çoğunun egemenliği ile ilgili statüko bozulmamıştı. Oniki Ada'da mevcut durumun bozulması, 1911-1912 Trablusgarp Savaşı ile gerçekleşecekti.

İtalya 19. yüzyılda siyasi birliğini tamamladıktan sonra dönemin büyük güçlerinin içinde bulunduğu yeni koloniler edinme savaşının bir parçası oldu. Kuzey Afrika'da yatırımlarının olduğu Tunus'u hedefleyen İtalya, Tunus'un Fransızlar tarafından işgalinden sonra diğer güçlerin de teşviki ile Trablusgarp sancağına asker çıkardı. ${ }^{1} \mathrm{Bu}$ işgal, Osmanlı subaylarının bölgede yaşayan Senüsilerle ${ }^{2}$ bir direniş organize edip düzensiz savaş taktiği uygulamasından sonra İtalyanlar için neredeyse bir savunma savaşı haline geldi. ${ }^{3}$ Bölgede bulunduğu çıkmazdan kurtulmak isteyen İtalya savaş öncesi diğer Avrupa devletlerine aksi yönde söz vermesine rağmen, savaşı Akdeniz'e yayıp Beyrut gibi önemli Doğu Akdeniz limanlarını bombaladı. ${ }^{4}$ Nisan 1912 'de ise İtalyan donanması Ege Denizi ve Boğazlar bölgesine harekât başlatıp Oniki Ada'yı işgal etti. ${ }^{5}$

Oniki Ada’nın bu dönemdeki işgaliyle ilgili iki önemli değerlendirme yapılmalıdır. Birincisi, İtalya'nın Oniki Ada'yı işgal ettikten sonra Muğla/Marmaris gibi Anadolu sahillerindeki bazı bölgeleri bombalamasıdır. ${ }^{6}$ İtalyan La Stampa gazetesi işgalden sonra Batı Anadolu'da kentlerde yaşanan panik havasını yazıyor ve İzmir gibi önemli bir kentin dahi tehlike altında olduğunu söylüyordu. ${ }^{7} \mathrm{Bu}$ durum $1920^{\prime}$ ler ve 1930 'lar boyunca sürecek ve aşağıda ayrıntısıyla incelenecek olan adalardan Batı Anadolu'ya yöneltilecek bir saldırı tehdidi mefhumunun başlangıcını oluşturur. Bir başka deyişle, Türkiye'nin iki savaş arası dönemin çoğunda yaşayacağ “işgal korkusu"nun tarihsel bir altyapısının olduğunu göstermektedir. İkinci önemli değerlendirme ise, Oniki Ada'nın 1912 itibariyle, yasal olmasa da fiilen Osmanlı idaresinden çıkması, bu sebeple de önce İmparatorluk sonra da Cumhuriyet devrinde bölgede stratejik bir zaaf oluşturmasıdır.

1912'den 1923'e uzanan önemli süreçte, Oniki Ada'nın geleceği diplomatik alanda çokça tartışıldı. Balkan Savaşları sırasında Yunanistan'ın da Kuzeydoğu Ege Adaları'nı işgal etmesi, Birinci Dünya Savaşı'na kadar bu iki grup adayı, birlikte uluslararası konferansların önemli bir konusu haline getirdi. ${ }^{8}$ Sonuçsuz kalan fakat fiilî işgal durumunu değiştirmeyen bu görüşmelere ek olarak 1914 yılında Birinci Dünya Savaşı'nın başlaması adaların jeopolitik konumunu öne çıkardı. Akdeniz'deki stratejik konumları sebebiyle her daim önemsenmiş bu adalar, savaş boyunca askerî açıdan kullanıldı. Oniki Ada'nın savaş sırasında Anadolu'ya karşı kullanılabileceği istihbaratına karşı Osmanlı Hükümeti Güney ve Batı Anadolu'da önlemler

\footnotetext{
${ }^{1}$ Hale Şıvgın, Trablusgarp Savaşı ve 1911-1912 Türk-Ittalyan Ilişskileri: Trablusgarp Savaşı'nda Mustafa Kemal Atatürk'le Illgili Bazı Belgeler, Türk Tarih Kurumu Basımevi, Ankara 1989, s.2.

${ }^{2}$ Senüsilik 19. yüzyılda Mekke'de kurulan ve Libya'da oldukça etkili olan bir İslam tarikatıdır.

${ }^{3}$ Timothy Winston Childs, Trablusgarp Savaşı: Türk-İtalyan Diplomatik Illişkileri (1911-1912), Türkiye İş Bankası Kültür Yayınları, İstanbul 2008, s.108-109.

${ }^{4}$ Age, s.89-91.

${ }^{5} \mathrm{Bu}$ konudaki belgeler için, bakınız: Bilal N. Şimşir, Ege Sorunu: Belgeler (1912-1913), C.1-2, Türk

Tarih Kurumu Basımevi, Ankara 1989.

${ }^{6}$ Age, C.1, s.74.

7 "L'enorme Panico diffuso tra i torchi dell'Archipelago dalle navi Italiane", La Stampa, 23 Nisan 1912.

${ }^{8}$ Daha ayrıntılı bilgi için bknz: Ronald John Lagoe, Greece and the Great Powers: The Question of the Aegean Islands, 1912-1914, Michigan University of Microfilms, Ann Arbor, 1976; Richard Bosworth, "Britain and Italy's Acquisition of the Dodecanese, 1912-1915", The Historical Journal, C.13, S.4 Aralık 1970, s.683-705.
} 
aldı. ${ }^{9}$ Beklenenin aksine, İtilaf Devletleri savaş sırasında buradan Anadolu'ya bir çıkarma taarruzuna yeltenmedi, fakat savaşın büyük bir kısmında Rodos ve Leros gibi adaları bölgede üs olarak kullandı. ${ }^{10}$ Savaş bittikten sonra ise Oniki Ada Güneybatı Anadolu'daki İtalyan işgalleri için bir atlama tahtası işlevini gördü.

Bu tarihsel arka planla düşünüldüğünde, adaların kurulacak olan Türkiye Cumhuriyeti'nin askerî planlarında önemli yer tutması şaşırtıcı değildir, çünkü adalar her ne kadar ana kara açısından küçük olsalar da coğrafi olarak Anadolu'ya yakınlıkları Batı Anadolu'ya tehdit unsuru oluşturabilmektedir. Üstelik bu coğrafi konum 1912'den sonraki tarihsel hafiza ve iki savaş arası dönemin aşağıda incelenecek diplomatik dinamikleri ile beraber düşünüldügünde Türkiye'nin bu dönemde adalarda olan herhangi bir hareketliliğe karşı hassasiyeti daha rahat anlaşılmaktadır.

\section{İki Dünya Savaşı Arasında Türkiye ve Oniki Ada}

1923 yılında Lozan Antlaşması'nın imzalanması ile Türkiye Oniki Ada'yı - Meis'i (Kastellorizo) de içerecek şekilde- İtalya'ya resmen bırakmış oldu. Lozan Antlaşması'nın TBMM'de onaylanması sırasında yapılan konuşmalarda İstanköy (Kos) doğumlu olan parlamenter Şükrü Kaya'nın adalarla ilgili sözleri aslında gelecek günlerin habercisi gibiydi:

HISTORY STUDIES

145

Volume 9

Issue 5

December 2017

"Boğazlardan sonra Midilli, Sakız ve Sisam adaları vardır. Rica ederim benimle beraber tekrar haritayı göz önüne getiriniz. Bu adalar Anadolu'dan kopmuş güzel birer parçadır... Bu adalar yabancı ellerde bulundukça bize sahillerde yaşamak imkânı var mıdır? Sahillerimizin temini asayişi için edeceğiniz mütevali fedakârlıklar bu adaların zabıt ve raptından daha ziyade güç olacaktır... Bu adalar sırf Anadolu'nun müdafaası için yaratılmıştır... Efendiler! Yunanistan'a bahşedilen Sisam adasından aşağıya doğru gidecek olursak daha birtakım adalara tesadüf ederiz... Bunlar içerisinde Rodos gibi İstanköy, Meis gibi Anadolu'ya bitişik ve Türklerle meskûn kıymetli adalar vardır... Bu adalar bence İtalyanların elinde Anadolu'ya doğru uyanacak bir istismar ve istismar siyasetinin bir mukaddimesidir..."11

Gerçekten de 1923 yılı itibarıyla İtalya Akdeniz'de önemli bir stratejik konuma sahip Oniki Ada'yı silahlandırmaya başladı. Bu silahlandırma sürecinin temelinde ise İtalyan dış politikasının saldırgan ve genişlemeci tavrı yatıyordu. İktidarı 1922'de ele geçiren Benito Mussolini büyük güçlerin en küçüğü olan İtalya'yı eski Roma İmparatorluğu'nun ihtişamına kavuşturmayı vaat etmiş ve bu hedefin doğal sonucu olarak da Akdeniz coğrafyası İtalya'nın genişlemeci programının bir parçası haline gelmişti. ${ }^{12} \mathrm{Bu}$ bakımdan, yeni kurulan ve 1920'lerin başında henüz tam olarak güçlenememiş; dış politika açısından da kırılgan bir durumda olan Türkiye de Mussolini İtalya'sının ana hedeflerinden birini oluşturuyordu. ${ }^{13}$ Dolayısıyla, Doğu Akdeniz'e hâkim ve Türkiye sahillerinin hemen karşısında bulunan Oniki Ada İtalya'nın bölgedeki siyasi ve askerî hedefleri açısından kilit bir konuma yerleşti.

\footnotetext{
${ }^{9}$ İsrafil Kurtcephe, Türk-İtalyan İlişkileri (1911-1916), Türk Tarih Kurumu Basımevi, Ankara 1995, s.238-246.

${ }^{10}$ Archivio Storico Diplomatico del Ministero degli Affari Esteri (ASDMAE), Pacco Dodecanneso 986,

"Sistemazione delle Isole Egee," 14 Mayıs 1923.

${ }^{11}$ TBMM Zabıt Cerideleri, İçtima: 7, Cilt: 3, 21.8.1339, s.238.

${ }^{12}$ H. James Burgwyn, Italian Foreign Policy in the Interwar Period, 1918-1940, Greenwood Press, Wesport 1997, s.18.

${ }^{13}$ Dilek Barlas, "Friends or Foes? Diplomatic Relations between Italy and Turkey, 1923-1936,"

International Journal Middle East Studies, C.36, S.2 2004, s.232-237.
} 
Bu emeller doğrultusunda İtalya 1923'ten itibaren özellikle Rodos ve Leros'un askerî olarak yeniden yapılandırılması konusunda bazı adımlar atmaya başladı. İtalyan Dışişleri Bakanlığı'nın arşivlerinde bulunan Oniki Ada klasörleri 1920'ler ve 1930'lar boyunca adadaki askeri yapılanmayı, asker ve silah sevkiyatını açıkça göstermektedir. İtalyanların 1923'ten başlayarak Rodos'u Oniki Ada'nın askerî merkezi olarak yapılandırdığı, Leros Adası'nı ise deniz üssü olarak seçip bu üsleri güçlü hale getirmek için hangarlar, kışlalar inşa edildiği görülmektedir. ${ }^{14} 1924$ 'ten itibaren bu adalara daha yoğun asker ve silah sevkiyatı gerçekleştirilmeye başlanmıştı. ${ }^{15} \mathrm{Bu}$ hazırlıkların hedefinde ise Türkiye vardı.

1923 ve 1924 'te gerçekleşen bu hazırlıkların Türkiye'ye yansıması Türklerin dikkatlerini batıdaki güvenliğe çevirmesi şeklinde oldu. Türkiye bir taraftan karşı kıyıda gerçekleşen bu hareketleri dikkat ve kaygıyla izlerken diğer taraftan da ülkenin batısının güvenliğini ciddi bir biçimde ele almaya başladı. Örneğin, 1924 yılında Türk ordusu İzmir'de geniş çaplı bir manevra gerçekleştirdi. ${ }^{16}$ Ordunun bu manevrası İtalyan istihbaratı tarafından ayrıntılı olarak not edilmiştir. Bu notlara göre, bu dönemde İzmir'deki birkaç bölge hariç Türkiye sahillerden gelecek herhangi bir saldırıya çok da hazırlıklı değildi; dolayısıyla Ankara'nın 1924 yılı itibarıyla İzmir' in güneyindeki bölgeleri askerî açıdan güçlendirmek için ciddi çaba sarf etmesi gerekiyordu. ${ }^{17}$

Karşı kıyıda sürekli bir hareketliliğin olduğu bu dönemde Ankara da batıdaki bu eksikliklerini gidermeye çalıştı. Örneğin kıyı bölgelere toplar yerleştirilip cephane sevkiyatı yapılırken, Aydın ve Manisa gibi daha iç bölgelerde de asker sayısı neredeyse iki katına çıkarıldı. ${ }^{18}$ Yine aynı şekilde Muğla'ya ve daha sonra da özellikle Meis adasındaki hareketliliğe binaen Antalya'ya da toplar yerleştirilip asker sevk edildi. ${ }^{19}$ Türkiye'nin yaptığg 1 çalışmaları gün gün not tutan İtalyan istihbarat belgelerine göre Türkiye, Datça gibi ulaşım ve tahkimatın zor olduğu bölgelerde, olası bir İtalyan çıkarmasına direniş gösterilmesi için halka dahi silah dağıtmıştı. ${ }^{20}$ Bazen bunun aksine Güneybatı Anadolu'da tahkim edilen bazı bölgelere sivil halkın girişi yasaklanmıştı. Türkiye'nin tüm bu silahlandırma çabası adalardaki askerî duruma dair gelen istihbarat raporlarına göre şekilleniyordu. Bir başka deyişle, askerî hareketlilik istihbaratının geldiği adanın tam karşı kıyısı adeta bir etki-tepki prensibine göre silahlandırılıyordu. Bu durum, olası bir İtalyan saldırısının ciddi olarak beklendiği 1927 tarihine kadar aynı hızda devam edecekti.

1923 ve 1927 arasındaki bu dönem yeni kurulan Türkiye'nin bazı başka diplomatik sorunlarla da ilgilenmek zorunda kaldığı bir zaman dilimine tekabül eder. Adalardan gelen İtalyan tehdidine ek olarak Türkiye'nin, İngiltere ile çözmesi gereken Musul gibi önemli bir sorunu ve mübadeleden doğan bazı meselelere ilişkin Yunanistan ile diplomatik problemleri bulunuyordu. 1924 yılında olası bir İtalyan tehdidine karşı hazırlanan Türkiye için diplomatik durum 1924 yılının son aylarından itibaren daha karmaşık bir hale büründü. Türkiye'nin özellikle 1925 yılı itibarıyla, diplomatik olarak sıkıntı yaşadığı bu iki ülke ile İtalya'nın iş

\footnotetext{
${ }^{14}$ ASDMAE, Pacco Dodecanneso 986, “Visita a Lero,” 19 Ekim 1923.

${ }^{15}$ ASDMAE, Pacco Dodecanneso 988, "Forze Militari nel Dodecanneso," (Military Forces in the Dodecanese), 25 Subat 1924.

${ }^{16}$ Dilek Barlas-Serhat Güvenç, Turkey in the Mediterranean during the Interwar Era: The Paradox of Middle Power Diplomacy and Minor Power Naval Policy, Indiana University Turkish Studies, Indiana 2010, s.41.

${ }^{17}$ ASDMAE, Pacco Turchia 1700, "Convegno Militare a Smirne," 9 Şubat 1924, 19 Şubat 1924; Pacco Turchia 1700, "Mustafa Kemal e ...Militari," 20 Şubat 1924.

${ }^{18}$ ASDMAE, Pacco Turchia 1701, "Italia e Turchia," 7 Temmuz 1924; ASDMAE, Pacco Turchia 1701, "n.t." 28 Haziran 1924.

19 ASDMAE, Pacco Turchia 1704, "Armamenti Turchi," 30 Temmuz 1924; Pacco Turchia 1704, "Armamenti Turchi nella zona di Adalia," 5 Eylül 1924.

${ }^{20}$ ASDMAE, Pacco Turchia 1704, “Armamenti Turchi,” 30 Temmuz 1924.
} 
birliği içinde olabileceğinden, olası bir İtalyan saldırısında da birkaç cephede birden savaşmak zorunda kalabileceğinden şüphelendiği görülür. Bu bakımdan Türkiye'deki yerel ve ulusal basının, İtalya'nın adalardaki askerî hazırlıkları Türkiye'yi işgal etmek için yaptığını yazması ve İtalya, İngiltere ile Yunanistan'ın iş birliği içinde olduğunu vurgulaması önemlidir. ${ }^{21}$

Gerçekten de bu dönemde İngiltere Başbakanı Chamberlain ile Mussolini birkaç kez bir araya gelmiş, bu görüşmelerden sonra Mussolini İtalyan Savunma Bakanı'na Türkiye ile olası bir savaş planı üzerinde çalışmasını emretmişti. ${ }^{22}$ Musul meselesinde istediği sonuca ulaşmak isteyen İngiltere, İtalya ile iş birliği yapmaya karar vermişti. Yunan arşiv belgelerine göre de Musul için yapılacak olası bir savaşta, İtalya İngiltere'ye Türkiye'ye gönderebileceği 250.000 askerin sözünü vermişti. ${ }^{23}$ İktisadi ve askerî kaynakların kısıtlı olduğu böylesi bir dönemde Türkiye bir taraftan Batı Anadolu'yu güçlendirmeye çalışırken diğer taraftan doğuda da Musul sebebi ile askerî yığınak yapmaya çalışıyordu. Üstelik bu iki durum tarafların birbirine yakınlaşması ile daha da tehlikeli bir hal almıştı. Bu denkleme kısa bir süre sonra bir de Yunanistan dahil olacaktı.

1925 yılında General Pangalos Yunanistan' da yönetimi bir darbe ile ele geçirdi. Generalin de Yunanistan'ın topraklarını genişletmek hedefi üzerinden temellenen bir dış politika anlayışı vardı. Bu bağlamda hedefleri içindeki Türkiye'ye dair emellerini gerçekleştirmek için İngiliz ve İtalyanlara yaklaşmaya çalışıyordu. İngiliz Ulusal Arşivleri'ndeki bir belgeye göre, İtalyanlar ve Yunanlar "Küçük Asya"da ortak bir harekât için Cenevre'de bir araya gelip anlaşmaya çalışmışlardı. ${ }^{24}$ Londra, olası bir İtalyan-Yunan iş birliğinin ileride alabileceği şekilden hoşlanmadığ ${ }_{1}$ için bu girişimi desteklememişti, ${ }^{25}$ ama bu durumun tam da Musul Sorunu'nun çözümü sürecinde Türkiye'yi sıkıştırması sebebiyle aksi bir tavır da almamıştı.

Halihazırda mübadeleden doğan sorunlarla ilgili sıkıntılı olan Türk-Yunan ilişkileri,

General Pangalos'un dış politikadaki adımlarıyla daha da gerildi. Yunanistan Sakız ve Midilli gibi adalarını Lozan'daki statüye rağmen askerîleştirirken Türkiye de cevaben Dikili, Bergama, Edremit gibi bölgelere asker ve mühimmat göndermeye başladı. ${ }^{26}$ Türkiye'nin batı sahilleri hem kuzeyden hem de güneyden tehlike altındaydı. Görüldüğü gibi, Türkiye bu dönemde üç farklı devletin tehdidi ile karşı karşıyaydı. Ve 1923'te tekil bir tehdit unsuru olarak ortaya çıkan Oniki Ada birden Türkiye'nin başka diplomatik sorunlarının da bir parçası haline gelmişti. Musul Sorunu incelenirken Türkiye'nin içinde bulunduğu bu zorlu diplomatik ve askerî koşulların göz önünde tutulması 1926'da alınan kararın tüm dinamikleriyle ortaya konulmasında yardımcı olacaktır.

1926'da Musul Sorunu'nun çözümünden sonra İtalya'nın Türkiye ile ilgili duruşu değişti ve tarafların komşuluk ilişkileri normale döndü. ${ }^{27}$ İlişkilerin normalleştiği bu süreçte Oniki Ada konusunda ilerleyen sayfalarda da değinilecek sınır sorunları müzakere masasına yatırıldı. Fakat diplomatik ilişkilerin geliştiği bu birkaç y1ldan sonra Ege'de yeniden tansiyonun yükseldiği dinamiklere geri dönüldü. 1930'ların ikinci yarısı, Oniki Ada'nın Türk dış ve güvenlik politikasında yeniden bir tehdit unsuruna dönüştüğü bir başka dönem oldu.

${ }^{21}$ ASDMAE, Pacco Turchia 1700, “Presunti Concentramenti Truppe Italiane," 1 Haziran 1924.

${ }^{22}$ Peter Edwards, "The Austen Chamberlain-Mussolini Meetings", The Historical Journal, C.14, S.1 1971, s.153-154.

${ }^{23}$ Antonis Klapsis, "Attempting to Revise the Treaty of Lausanne: Greek Foreign Policy and Italy during the Pangalos Dictatorship, 1925-1926,” Diplomacy and Statecraft, S.25, C.2 May1s 2014, s.244.

${ }^{24}$ The National Archives, FO 286/1024, "Situation in the Dodecanese Islands," 22 Şubat 1928.

${ }^{25}$ Klapsis, age, s.247.

${ }^{26}$ TC Başbakanlık Cumhuriyet Arşivi, 30.10.0.0/253.708..17, 28 Mart 1925; ASDMAE, Pacco 1709 Turchia,

"Inicidente del Patriarcato- Misuri Militare Turche,", 26 Şubat 1925.

${ }^{27}$ Değişen ilişkiler ve sonuçları için bkz. Dilek Barlas, "Friends or Foes?” s.237-243. 
1930'larda Ege'de sıkıntılı dönemin yeniden başlaması birkaç olayın üzerine oldu. Bunlardan bir tanesi, İtalya'nın, Oniki Ada ve Kiklad Adaları arasında kalan bazı Yunan adacıklarını ileride yapacağı savaşlarda kullanmak üzere işgal etmesiydi. ${ }^{28} 1933$ yılında gerçekleşen Ege'deki bu işgal hareketi İtalya ve Yunanistan arasında gibi görünse de Türkiye'nin adalar temelli güvensizliğini tetikledi. Ardından 1934 yılında İtalyan lideri Mussolini daha sonra literatüre "tariĥ̂" olarak geçecek bir meclis konuşması yaptı. Bu konuşmada, Afrika ve Asya'yı İtalya'nın doğal hinterlandı olarak gösterdi. ${ }^{29}$ Bu konuşma hem Türkiye'de hem de Yunanistan'da büyük bir infial yarattı. Öyle ki Türkiye Büyük Millet Meclisi'nde bu konuşma üzerine çeşitli oturumlar düzenlendi. ${ }^{30}$ Türkiye yeniden 1920 'lerin başındaki dinamiklere geri dönmüş ve hem dış politikasını hem de savunma stratejisini Oniki Ada'daki duruma göre planlamaya başlamıştı.

Fakat 1930'ların ikinci yarısında Ege'deki genel durum 1920'lerle kıyaslandığında Türkiye için daha olumlu bir hal almıştı. İçte rejimini güçlendiren Türkiye, dış siyasette de yaşadığı birçok sorunu çözmüştü. Örneğin, Ankara ve Atina arasındaki ilişkiler 1920'lerin başındakinden çok farklı olarak güçlü bir iş birliğine dönüşmüştü. Oniki Ada'daki İtalyan varlığı artık Yunanistan için de bir tehdit unsuruydu. Atina Oniki Ada'da devam eden inşa ve yığınak programını dikkate alıyor ve Kuzeydoğu Ege adalarının yakınında özellikle İtalyan tehdidine karşı tatbikatlar gerçekleştiriyordu. ${ }^{31}$ Zaten Oniki Ada'daki durum ve İtalyan genişlemeciliği bir süre sonra Yunanistan ile Türkiye'nin ortak manevra ve ortak savunma gibi konularda müzakereler yürütmesini de beraberinde getirdi.

Türkiye tüm bu süreçte gözünü yeniden batıdaki güvenliğe çevirdi. Bu bağlamda, Edremit'ten Antalya'ya kadar olan bölgeyi askerî olarak güçlendirmeye çalıştı. İtalyan istihbarat belgelerine göre, Türkiye 1934 yllında sadece İzmir'den Antalya'ya kadar olan bölgeye 150.000 asker konuşlandırmıştı. ${ }^{32}$ Fakat 1930 'larda Türkiye'nin kendisini adalardan gelecek bir saldırıya karşı korumak için aldığ 1 tek önlem askerî alanda cereyan etmedi. Türkiye, aynı zamanda aktif bir haricî siyaset izlemeye başladı.

Bunlardan bir tanesi Türkiye'nin çevresinde anti-revizyonist bir pakt oluşturma çabasıydı. Tarihçi Stavrianos'a göre Türkiye ve Yunanistan aralarındaki problemleri çözdükten sonra Balkanlardaki anti-revizyonist cephenin en önemli dayanağ 1 olmuştu. ${ }^{33} \mathrm{Bu}$ iki devletin uzun süreli çabaları sonucunda 1934'te Balkan Antantı imzaland. Türkiye, Yunanistan, Romanya ve Yugoslavya'nın katıldığı Antant, sosyo-kültürel ve iktisadi bir yakınlaşma olduğu kadar Akdeniz ve Balkanlarda revizyonizm karşıtı bir siyasi yönelimin sonucuydu.

Bunun dışında Türkiye, yine bu dönemde, Boğazlar bölgesini silahlandırmak için bazı adımlar attı. Ege'de sahil bölgelerini güçlendiren Türkiye, Çanakkale civarını askerden arındırılmış statüsü sebebiyle silahlandıramıyordu. Boğazların bu durumu stratejik açıdan önemli bir zafiyetti ve dolayısıyla Türkleri rahatsız ediyordu. 1934 yılında adalarda yapılan tahkimat haberlerinden ve Mussolini'nin yukarıda değinilen konuşmasından sonra Cumhurbaşkanı Mustafa Kemal Atatürk Çanakkale'ye bir gezi gerçekleştirdi. ${ }^{34}$ Dışişleri Bakanı Tevfik Rüştü Aras da adalardan gelecek bir saldırıya karşı Çanakkale Boğazı'nın savunmasız halde olduğuna ve mevcut durumun değiştirilmesi gerektiğine dair bazı Avrupa

\footnotetext{
${ }^{28}$ ASDMAE, Busta Dodecanneso 7, “Isolotti di Levita, Mauro, Laro, Kinaro, Liadi," 26 Eylül 1933.

${ }^{29}$ Yücel Güçlü, “Fascist Italy’s 'Mare Nostrum' Policy and Turkey,” Belleten, C.13, S.238 Aralık, 1999, s.816.

${ }^{30}$ TBMM Zabıt Ceridesi, Devre: 4, Cilt: 21, İçtima Senesi: 2, 5 Nisan 1934, s.15-17.

${ }^{31}$ ASDMAE, Busta Dodecanneso 7, "Concentramento di Truppi Italiane nel Dodecanneso," 10 May1s 1934.

${ }^{32}$ ASDMAE, Busta Turchia 11, "Informazioni," 21 Ekim 1934.

${ }^{33}$ L. S. Stavrianos, The Balkans since 1453, Hurst, Londra 2000, s.736.

${ }^{34}$ ASDMAE, Busta Turchia 11, "Questione degli Stretti," 9 May1s 1934.
} 
başkentlerinde mütalaalarda bulunmaya başladı. ${ }^{35} 1934$ yılında Türkiye'nin bu isteği uluslararası konjonktür sebebiyle pek kabul görmedi. Fakat 1935 yılında İtalya'nın Habeşistan'a saldırması Akdeniz'de mevcut konjonktürü tamamıyla değiştirip Türkiye'nin meseledeki pozisyonunu güçlendirdi. Ankara'nın diplomatik girişimlerinin artması ile 1936 y1lında Montreux Boğazlar sözleşmesi imzalandı. Türkiye Boğazlardaki seyir rejimi konusunda geniş yetkiler kazanırken bölgeyi silahlandırma hakkını da elde etti. Sözleşmenin onaylanmasından hemen sonra Türkiye Çanakkale'yi silahlandırarak Batı Anadolu'da hissettiği güvenlik boşluğunu doldurmuş oldu.

İtalya'nın Habeşistan'a saldırmasının Türkiye için uzun vadeli bir başka sonucu, Türkiye ve İngiltere'nin yakınlaşması oldu. İtalya'nın Habeşistan'a saldırısı Akdeniz'deki dengeleri bozduğundan İngiltere ve İtalya bu dönemde Akdeniz'de neredeyse savaşın eşiğine gelmişti. ${ }^{36}$ Tüm bu gelişmelerden sonra Türkiye uluslararası arenada Oniki Ada'daki İtalyan hazırlıklarından duyduğu endişeyi daha rahat bir biçimde anlatır olmuştu. Hatta Habeşistan krizi sırasında İngiliz ve Türk donanmaları Ege açıklarında dönem dönem birlikte seyretmişlerdi. ${ }^{37}$ Türkler ve İngilizler arasındaki bu iş birliği İtalyanları $1935^{\prime}$ in ikinci yarısında bir hayli rahatsız etmişti. İtalyanlar özellikle bu dönemde Türkiye anakarasından desteklenecek ve İngiliz donanması tarafından gerçekleştirilecek bir Oniki Ada operasyonundan, yani Akdeniz'deki en önemli üssünü kaybetmekten ciddi bir biçimde korkmuştu. $^{38}$ İtalyanların korkusunun aksine Türkiye'nin bu bölgeyi ele alan önlem ve girişimleri en azından 1939'a kadar hep defansifti. Zaten kriz atlatıldıktan sonra İngiltere, İtalya'yı Almanya'ya daha fazla yakınlaştırmamak için dikkatli bir politika izleyecek ve Türkiye de İtalya'nın Habeşistan'dan sonraki amacının Türkiye olduğundan şüphelenerek kıyılarındaki askerî düzenlemelerine savunma mantığında devam edecekti.

Türkiye'nin askerî ve diplomatik alanda devam ettirdiği çalışmalarının seyri 1937 yılında coğrafi olarak genişledi. Bunun en önemli sebeplerinden bir tanesi, 1936 sonrasında ortaya çıkan Hatay meselesiydi. Hatay, Suriye'deki milliyetçilerin Fransız mandater yönetimi ile bağımsızlık için müzakere masasına oturmasından sonra Türkiye'nin gündemine oturdu. ${ }^{39}$ Türkiye, mandater sistemin içinde otonom bir bölge olan İskenderun Sancağı'nın geleceği için Fransızlarla müzakereye başladı. Bu mesele Fransa-Suriye-Türkiye ilişkileri ile alakalıydı. Fakat Türk Genelkurmayı'nın arşivinde mevcut olan istihbarat belgelerine göre, İtalyanlar hem Hatay'da hem de Suriye'nin Halep gibi çeşitli kentlerinde yoğun propaganda faaliyeti gösteriyordu. ${ }^{40}$ Hatay'ın Türklere değil de İtalyanlara bırakılması için yapılan bu propaganda faaliyetleri Türk Genelkurmayı'nın dikkatini çekmişti. Bu sebeple Türkiye askerî açıdan Hatay'dan İzmir'e kadar olan bölgeyi bir bütün olarak gözden geçiriyordu. Gerçekten de Mareşal Fevzi Çakmak'ın uzun teftiş gezilerini Hatay'dan başlayarak Muğla'ya kadar yapması, arşivdeki İtalyan propagandası belgelerinin yoğunluğu da düşünüldüğünde, Türkiye'nin batısındaki tehdit algısını alakasız gibi görünen bu meselede dahi önemsediğine işaret etmektedir.

\footnotetext{
${ }^{35}$ ASDMAE, Busta Turchia 11, "Stampa Ellenica: Questione di Dardanelli," 26 Nisan1934.

${ }^{36}$ Robert Mallett, "The Italian Naval High Command and the Mediterranean Crisis, January-October 1935," Journal of Strategic Studies C.22, S.4 1999, s.80-90.

${ }^{37}$ ASDMAE, Busta Dodecanneso 9, "Movimenti della Flotta Brittanica e Attivita Militare Turca di Fronte alle Isole del Egeo," 16 Ekim 1935.

${ }^{38}$ Mallett, age., s.90.

${ }^{39}$ Hatay meselesi ile ilgili daha ayrıntılı bir anlatı için bkz: Serhan Ada, Türk-Fransız İlişkilerinde Hatay Sorunu, 1918-1939, İstanbul Bilgi Üniversitesi Yayınları, İstanbul 2013.

${ }^{40}$ Genelkurmay ATASE Daire Başkanlığ 1 Arşivi, İkinci Dünya Savaşı Belgeleri, 7-22/1, 25 Ocak 1937.
} 
Türkiye'nin askerî stratejisindeki bu coğrafi genişleme sadece güneye özgü de değildi. 1937'den itibaren, Kuzey Batı Anadolu'da da Bulgaristan, özellikle İtalya ile iş birliği içinde bir tehdit unsuru olarak görülüyordu. 1937'de biri Trakya'da bir diğeri de Aydın Söke'de olmak üzere yapılan iki büyük askeri manevra, Trakya'dan Bulgaristan'ın, Ege'den de İtalya'nın olası saldırısına karşı formüle edilmişti. ${ }^{41}$ Bulgaristan'ın da bu denkleme girmesi hem diplomatik hem de askerî iş birliği açısından Yunanistan ve Türkiye'yi birbirine iyice yaklaştırdı. Bu iki devlet 1938 yılında 1930'dakine benzer bir dostluk anlaşması yaptı. Bunun dışında yine bu dönemde çıkan haberlere göre, Yunan ve Türk Genelkurmayı gizli bir takım görüşmelerle olası bir Bulgar ve İtalyan saldırısına karşı ortak bir savunma planı dahi belirlemişti. ${ }^{42}$ Hatta İtalyanlar, bu ortak savunma planlarında Yunanistan'ın böyle bir saldırıda Türkiye'ye, Anadolu'ya yakın Sakız, Midilli gibi Yunan adalarını savunma izni dahi verdiğini iddia ediyordu. ${ }^{43}$ Böyle bir durumun varlığ 1 belgelerle kanıtlanamasa da Ege'deki durumun Türkiye ve Yunanistan'ı birbirine daha da yaklaştırdığı rahatlıkla söylenebilir.

Oniki Ada ve genel olarak Akdeniz'deki durumun Türkiye'ye bir başka yansıması, Ankara ve Londra'nın birbirine yakınlaşmasıydı. Her ne kadar İngiltere Habeşistan meselesinden sonra İtalya'yı Almanya'ya daha da yaklaştırmamak için uzlaşmacı bir politika izlese de bu durumun 1938 'den sonra sürdürülemez olduğu ortaya çıktı. Bu, Türkiye ve İngiltere'nin ittifakına giden yolu araladı. 1939 yılında önce İngiltere ve sonrasında da Fransa ile bir deklarasyon imzalayan Türkiye, Akdeniz'de bir saldırıya maruz kaldığı takdirde Fransa ve İngiltere'nin yardımını elde etmiş oldu. ${ }^{44}$ Türkiye deklarasyondan sonra müttefikleri ile yaptığı siyasi ve askerî toplantılarda Oniki Ada meselesini sık sık masaya yatırdı. Hatta, 1939 yılından Türkiye'nin savaşa girmeyeceğini belirttiği 1940 yılına kadar Türk ve İngiliz yetkililer Oniki Ada’yı ele geçirme planları hazırlad. ${ }^{45}$ İngiliz ve Fransız deniz ve hava kuvvetlerinin bölgede üstünlük sağlamasından sonra, Türk kara kuvvetlerinin adaları ele geçirmesine yönelik bu planlar, ${ }^{46}$ Türkiye'nin 2. Dünya Savaşı dışında kalma kararından sonra müttefikler tarafından rafa kaldırıldı. Fakat Türkiye Oniki Ada'yı tüm savaş boyunca takip etmeye devam etti.

\section{Ege'de Sinır Sorunları}

İki savaş arası dönemde Oniki Ada'nın ve genel olarak da Ege Denizi'nin Türk dış politikasındaki yeri, yukarıda bahsedilen İtalyan askerî hazırlıklarının Türkiye'nin askeri ve diplomatik kararlarını etkilemesi ile sınırlı değildi. 1923'te bölgenin egemenliğinin yasal olarak Anadolu karasından farklılaşması ortaya bir sınır sorunu çıkarmıştı. Bugün başka kavramlar üzerinden tartışlan ve Türk-Yunan ilişsilerinin temel problematiğini oluşturan bu sınır sorunu, iki savaş arası dönemde de Türkiye, İtalya ve Yunanistan arasında sık sık gerilime sebep oluyordu. Bu dönemde Ege'de sınır konusu, Meis Adası'nın etrafindaki adacıklarla ilgili olmak üzere 1923'ten hemen sonra başladı. Daha sonra ise Oniki Ada ve Türkiye arasındaki alanın tamamına yayılan bir mesele haline geldi.

\footnotetext{
${ }^{41}$ ASDMAE, Busta Turchia 21, "Manovre Turche in Tracia e Manovre Bulgare al Confine Turco," 15 Haziran 1937; TC Başbakanlık Cumhuriyet Arşivi, 30..10.0.0/5.26..2, 27 Eylül 1937.

42 ASDMAE, Busta Turchia 21, "Intesa Balcanica-Accordi Militari," 2 Mart 1938; age, "Rapporti Militari TurcoGreci," 17 Aralık 1937.

${ }^{43}$ Age.

44 İngiltere ile yapılan deklarasyon için bkz. İsmail Soysal, Türkiye’nin Siyasal Anlaşmaları: Tarihçeleri ve Açıllamaları ile Birlikte, C.1, Türk Tarih Kurumu Basımevi, Ankara 1989, s.591-599.

${ }_{45}$ Genelkurmay ATASE Daire Başkanlığ Arşivi, İkinci Dünya Savaşı Belgeleri, 3-038/1, 21 Haziran 1939.

${ }^{46}$ Age.
} 
Adaların devrinin gerçekleştirildiği Lozan Antlaşması'nın onaylanmasından hemen sonra Meis adacıklarının çevresinde bir işgal yarışı yaşandı. Lozan Antlaşması'nın 15. maddesinin Oniki Ada'nın genelindeki adacıkları bağlı bulunduğu adaya bırakması fakat Meis'i bu kategorinin dışında tutması, her iki tarafın da anlaşmanın bu maddesini istediği şekilde yorumlamasına neden oldu. ${ }^{47} \mathrm{Bu}$ sebeple, 1923 ve 1924 yıllarında iki taraf da Meis'e bağlı çeşitli adacıklara kendi bayraklarını dikip diplomatik bir krize neden olmuştu. ${ }^{48}$ Fakat Oniki Ada'daki gelişmeler, Türkiye'nin adalardan saldırı beklemesi ve Musul Sorunu dolayısıyla Ege'deki tansiyonun iyice yükselmesi bu meselenin çözülmesi için gereken diplomatik ortamı sağlamadığ 1 için adacık sorunu deyim yerindeyse donduruldu.

Daha önce belirtildiği gibi, 1920'lerin sonundan 1933'e kadar geçen sürede Türk-İtalyan ilişkileri nispeten normalleşti. Dolayısıyla Meis'e bağlı adacıklar sorunu taraflar arasında 1927'nin sonundan itibaren tartışılmaya başlandı. Fakat müzakere edilen konular bu adacıkların paylaşımından Ege'de Oniki Ada ve Türkiye arasındaki tüm sınırın belirlenmesine kadar genişledi. Türkiye için bu sınırı netleştirmek güvenlik için olduğu kadar iktisadi/ticari hususlar açısından da önemliydi. Örneğin, sınırın nerede başlayıp nerede bittiğinin kesin karara bağlanması, yabancı ülke gemilerinin ya da balıkçı teknelerinin bölgeye giriş ve çıkışının düzenlenmesi için elzemdi. İtalya, Lozan Antlaşması'nın öngördüğü üç mil şartının yeterince açık olduğunu ve bu sebeple de böyle bir anlaşmanın gerekli olmadığını savunuyordu. ${ }^{49}$ Türkiye ise bu konuda israrciydı. Hatta adacık müzakereleri sırasında dönemin Genelkurmay Başkanı Mareşal Fevzi Çakmak, İtalyan yetkililere böyle bir anlaşma olmadığı takdirde Meis için yapılacak herhangi bir düzenlemeyi veto edeceğini açıklamıştı. ${ }^{41}$

HISTORY STUDIES

151

Volume 9

Issue 5

December 2017

Sonuçta 1932 yılında imzalanan Anadolu kıyısı ve Meis arasındaki sınırı belirleyen antlaşma ile Meis'e bağlı adacıklar sorunu çözülmüş oldu. ${ }^{50}$ Taraflar aynı dönemde mektup teatisi yoluyla Oniki Ada ve Türkiye arasındaki sınırın tamamını belirleyecek bir müzakere sürecine gitme kararı da aldı 1932 y1lı boyunca Türk ve İtalyan yetkililer diplomatik görüşmelerle sınırı belirlemeye çalıştı. İtalyanlar bu süreçte sürekli bir biçimde Lozan Antlaşması'nın adacıkların bağlı bulundukları adaya verilmesini öngören 15. maddesini hatırlattı, zira Roma Ankara'nın Oniki Ada bölgesindeki bazı adacıkları da talep edeceğinden çekiniyordu. ${ }^{51}$ Gerçekten de görüşmeler sırasında Türkiye, Kalimnos ve Leros'a bağlı olduğu düşünülen ancak adalardan ziyade Türkiye'ye yakın olan iki adacığı talep etmişti. Bu durum aslında Ege'de daha sonra yaşanacak egemenliği tartışmalı adalar probleminin ilk nüvesini oluşturmaktadır.

Benzer şekilde, yine aynı görüşmelerde, Lozan'da ve uluslararası arenada genel olarak kabul gören üç millik karasuları sınırının genişletilmesine dair bazı müzakereler gerçekleşti. ${ }^{52}$

\footnotetext{
47 “15. Madde: Türkiye zirde tadat olunan adalar üzerindeki bilcümle hukuk ve müstenidatından Italya lehine feragat eder. Elyevm Italya'nın tahtı işgalinde bulunan Astampalya [Astropalia], Rodos [Rhodes], Kalki [Carki] Skarpanto, Kazos [Gasso], Piskopis [Tilos], Misiros [Misyros] Kalimnos [Kalymnos], Leros, Patmos, Lipsos [Lipso], Sombeki [Simi] ve lstanköy [Kos] adalart ile bunların tevabiinden olan adacılar ve Meis [Kastellorizo] adası." Başvekâlet Müdevvenat Müdiriyeti, Düstur, Üçüncü Tertip, C.5, Necmi İstikbal Matbaası, İstanbul 1931, s.27.

${ }^{48}$ Hazal Papuççular, War or Peace? The Dodecanese Islands in Turkish Foreign and Security Policy, 1923-1947 (Boğaziçi Üniversitesi Atatürk İlkeleri ve İnkılâp Tarihi Enstitüsü, Yayımlanmamış Doktora Tezi), İstanbul 2015, s.90-94.

${ }_{49}^{4}$ ASDMAE, Busta Dodecanneso 1, "Isolotti di Castelrosso," 14 Temmuz 1931.

50 "Anadolu sahilleri ile Meis Adasi arasındaki ada ve adacıkların ve Bodrum körfezi karşısındaki adanın ciheti aidiyeti hakkında İtalya Hükümet ile aktolunan itilâfname," Resmî Gazete, 25 Kanunusâni 1933, Kanun No:2106, S.2313, s.2173-74.

${ }^{51}$ ASDMAE, Busta Dodecanneso 3, "Delimitazione Acque Territoriali di Castelrosso," 26 Aralık 1932

52 ASDMAE, Busta Dodecanneso 5, "Frontiera Marittima tra la Turchia e di il Possedimento delle

Isole Italiane dell'Egeo," 24 Ocak 1933.
} 
Türkiye'nin karasularını belirleme çabasına karşı İtalya bu müzakerelerin sadece sınır tayin etmek için yapıldığını, bazı bölgelerde aynı anlama gelse dahi bir devletin karasularının ikili bir anlaşmaya tâbi olmadığını belirtti. ${ }^{53}$ Meis meselesinde hâkim olduğu alanı genişletmeye çalışan İtalya, Oniki Ada'nın genelindeki hudut tayininde çoğunlukla savunma pozisyonunda olduğu için daha muhafazakâr bir tavır takınmıştı.

1932 yılı müzakereler açısından oldukça çetin geçti. Hatta Türkiye bu sınır antlaşmasına verdiği önemi göstermek için Meis için imzalanan antlaşmanın onay sürecini 1932 y1lı boyunca tamamlamadı. ${ }^{54}$ Sonuç olarak, 1932 yılında taraflar arasında bir sinırlandırma protokolü kabul edildi, fakat değişen siyasi konjonktür sebebi ile bu nota hiçbir zaman yürürlüğe girmedi. Bu protokolün iki önemli sonucu bulunmaktadır. Birincisi, 1990'larda Türkiye ile Yunanistan'ı savaşın eşiğine getiren Kardak kayalıkları, bu sözleşmede bulunmakta ve sözleşmenin 30. maddesine göre İtalyan sınırları içinde kalmaktadır. Yunanistan bu sebeple Kardak kayalıklarının kendisine ait olduğunu iddia etmekte fakat Türkiye yapılan bu sözleşmenin onaylanmaması sebebiyle geçersiz olduğunu belirtmektedir.

İkincisi ise Ege'deki tartışmalı sınır sorunlarının ve karasuları meselesinin henüz 1920'ler ve 1930'lar gibi erken denilebilecek bir tarihte tartış1lıyor olduğudur. Üstelik bu durum sadece İtalya ve Türkiye arasındaki ilişkilerle de sınırlı değildi. Örneğin, Yunanistan ile Türkiye arasında da Kuzeydoğu Ege adalarına bağlı bazı adacıklar konusunda belirli görüşmeler yaşanıyor ve zaman zaman da karasuları tartışmaya açılabiliyordu. ${ }^{55}$ Benzer şekilde, yukarıda da belirtildiği gibi İtalya ve Yunanistan arasında da özellikle Oniki Ada ve Kiklat grubu arasındaki bölgede sınır ve adacık sorunları yaşanabiliyor bu sorunlar işgallere kadar varabiliyordu. Özetle, sınır sorunları tüm iki savaş arası dönem boyunca Ege'de hâkim üç devletin de uğraştığı karmaşık bir problemdi.

\section{Sonuç}

1923 'te Oniki Ada'nın İtalyan egemenliğine bırakılması ile Türkiye ve adalar arasındaki ilişski yeni bir boyut kazandı. İki savaş arası dönem boyunca Oniki Ada Türkiye'nin güvenlik stratejisinde önemli bir konuma sahip oldu. Dönemin büyük kısmında Oniki Ada'daki İtalyan varlığı ve askerî hazırlıkları Ankara için büyük bir tehdit algısı oluşturdu. Bu sebeple Türk yetkililer adalardan Anadolu'ya yöneltilecek bir tehdide karşı durabilmek için Batı ve Güneybatı Anadolu'da askerî önlemler aldı. Bununla beraber birçok meselede dış siyasetini de buna göre düzenledi. İki dünya savaşı arasındaki bu dönemde, adaların Türk dış politikasındaki yeri olası bir saldırı tehlikesi ile sınırlı da değildi. 1920'lerin sonundan 1930'ların ortalarına kadar Türk diplomasisi Ege Denizi'ndeki adacıkların egemenliği ve sınır sorunları ile de uğraştı. Günümüzde tarafların üzerinde hâlâ uzlaşamadıkları sınır meselesi bu dönemde de Türkiye, İtalya ve Yunanistan arasında çetin müzakerelere sahne oldu.

\footnotetext{
${ }^{53}$ ASDMAE, Busta Dodecanneso 5, "Delimitazione Marittima Frontiera Italo-Turca," 26 Aralık 1932.

${ }^{54}$ Age.

${ }^{55}$ ASDMAE, Pacco Dodecanneso 991, “Isolotti Passaro e Panaya,” 23 Şubat 1928.
} 


\section{Kaynakça}

\section{Arşiv Belgeleri}

ARCHIVIO STORICO DIPLOMATICO DEL MINISTERO DEGLI AFFARI ESTERI (ASDMAE),

Pacco Turchia, 1700, 1701, 1704, 1709.

Pacco Dodecanneso, 986, 988, 991.

Busta Dodecanneso 1, 3, 5, 7, 9 .

Busta Turchia, 11, 21.

GENELKURMAY ATASE DAİRE BAŞKANLIĞI ARŞIVİ,

İkinci Dünya Savaşı Belgeleri, 7-22/1, 3-038/1.

T.C. BAŞBAKANLK CUMHURIYET ARŞIVİ

30.10.0.0/253.708..17

THE NATIONAL ARCHIVES

FO 286/1024

\section{Kitap ve Makaleler}

ADA, Serhan, Türk-Fransı İlişkilerinde Hatay Sorunu, 1918-1939, İstanbul Bilgi Üniversitesi Yayınları, İstanbul 2013.

BARLAS, Dilek, "Friends or Foes? Diplomatic Relations between Italy and Turkey, 1923-1936," International Journal Middle East Studies, C.36, S.2 2004, s.231252.

BARLAS, Dilek, Güvenç, Serhat, Turkey in the Mediterranean during the Interwar Era: The Paradox of Middle Power Diplomacy and Minor Power Naval Policy, Indiana University Turkish Studies, Indiana 2010.

BAŞVEKALET MÜDEVVENAT MÜDİRIYETİ, Düstur, Üçüncü Tertip, C.5, Necmi İstikbal Matbaas1, İstanbul 1931.

BOSWORTH, Richard "Britain and Italy's Acquisition of the Dodecanese, 1912-1915", The Historical Journal, C.13, S.4 Aralık 1970, s.683-705.

BURGWYN, James Burgwyn, Italian Foreign Policy in the Interwar Period, 1918-1940, Greenwood Press, Wesport 1997.

CHILDS, Timothy Winston, Trablusgarp Savaşı: Türk-Italyan Diplomatik İlişkileri (1911-1912), Türkiye İş Bankası Kültür Yayınları, İstanbul 2008.

EDWARDS, Peter "The Austen Chamberlain-Mussolini Meetings", The Historical Journal, C.14, S.1 1971, s.153-64.

GÜÇLÜ, Yücel, “Fascist Italy's 'Mare Nostrum’ Policy and Turkey,” Belleten, C.13, S.238 Aralık, 1999, s.813-845.

KLAPSIS, Antonis, "Attempting to Revise the Treaty of Lausanne: Greek Foreign Policy and Italy during the Pangalos Dictatorship, 1925-1926," Diplomacy 
and Statecraft, S.25, C.2 May1s 2014, s.240-259.

KURTCEPHE, İsrafil, Türk-Italyan İlişkileri (1911-1916), Türk Tarih Kurumu Basımevi, Ankara 1995.

LAGOE, Ronald John, Greece and the Great Powers: The Question of the Aegean Islands, 1912-1914, Michigan University of Microfilms, Ann Arbor, 1976.

MALLETT, Robert, "The Italian Naval High Command and the Mediterranean Crisis, January-October, 1935," Journal of Strategic Studies, C.22, S.4 1999, s.77-102.

PAPUÇÇULAR, Hazal, War or Peace? The Dodecanese Islands in Turkish Foreign and Security Policy, 1923-1947 (Boğaziçi Üniversitesi Atatürk İlkeleri ve İnkılâp Tarihi Enstitüsü, Yayımlanmamış Doktora Tezi), İstanbul 2015.

SOYSAL, İsmail, Türkiye'nin Siyasal Anlaşmaları: Tarihçeleri ve Açıklamaları ile Birlikte, C.1, Türk Tarih Kurumu Basımevi, Ankara 1989.

STAVRIANOS, L. S. Stavrianos, The Balkans since 1453, Hurst, Londra 2000.

ŞIVGIN Hale, Trablusgarp Savaşı ve 1911-1912 Türk-Ittalyan İlişkileri: Trablusgarp Savaşı'nda Mustafa Kemal Atatürk'le Illgili Bazı Belgeler, Türk Tarih Kurumu Basımevi, Ankara 1989.

ŞİMŞİR, Bilal N., Ege Sorunu: Belgeler (1912-1913), C.1-2, Türk Tarih Kurumu Basımevi, Ankara 1989. 